\title{
DETERMINATION OF SUITABLE WINTER CHICKPEA (CICER ARIETINUM L.) CULTIVARS UNDER KAHRAMANMARAŞ CONDITIONS
}

\author{
Cengiz Yururdurmaz ${ }^{1, *}$, Mehmet Çağatay Çerikçi ${ }^{1}$, Rukiye Kara ${ }^{2}$, Ali Turan ${ }^{1}$ \\ ${ }^{1}$ KSU Faculty of Agriculture Department of Field Crop Kahramanmaraş, Turkey \\ ${ }^{2}$ East Mediterranean Transitional Zone Agricultural Research Institute, Kahramanmaraş, Turkey
}

\begin{abstract}
This study was conducted with the chickpea cultivars of Işık-05, Azkan, Sarı 98, Hisar, Çakır, Aydın 92, Yaşa-05, Menemen 92, Cevdetbey, Çağatay, Aksu and two local cultivars over the experimental fields of Kahramanmaraş Eastern Mediterranean Transitional Zone Agricultural Research of Institute in 2014-2015 cropping years. Experiments were conducted in randomized blocks design with 3 replications. Quality traits of plant height, the first pod height, number of branches per plant, number of pods per plant, number of kernels per plant, kernel weight per plant, kernel yield, 100-kernel weights were investigated. The differences in plant height, the first pod height, number of branches per plant, number of pods per plant, number of kernels per plant, kernel weight per plant, kernel yield and 100-kernel weight of the genotypes were found to be significant. Kernel yields of the genotypes varied between $425.40-267.93 \mathrm{~kg}$ da-1 with the greatest value from Çakır cultivar and the lowest value from Hisar cultivar.
\end{abstract}

Keywords: Chickpea, variety, yield, yield components

\section{INTRODUCTION}

Legumes supply $22 \%$ of plant-originated proteins and $7 \%$ of carbohydrates in human nutrition; $38 \%$ of proteins and 5\% carbohydrates in animal feeding (Wery and Grinac, 1983). Animal and plant products constitute the primary protein sources. Dry pulses contain about $18-37 \%$ protein based on species, cultivars, environmental conditions and growing methods, thus they have a significant place both in human nutrition and animal feeding (Eser, 1981). Chickpea kernels have quite a high protein contents and they constitute an important staple food in under-developed and developing countries. Chickpea kernels contain 38.1 - 73.3\% carbohydrate, $1.5-6.8 \%$ oil and $1.6-9.0 \%$ cellulose. In terms of oil content, chickpea is the richest pulse among the edible legumes. Chickpea protein is rich in amino acids including especially isoleucine, leucine and lysine with a great role in human nutrition; but poor in tryptophan, methionine and cystine (Şehirali, 1988). Besides high protein and carbohydrate contents, chickpea kernels are also rich in phosphorus, calcium and ironlike minerals and vitamin A, B and Niacin, thus have an important place in daily diets of humans (Smithson et al., 1985).

Previous studies conducted in regions with dominant Mediterranean climate conditions revealed that winter sowing offered various advantages in chickpea farming such as greater kernel yields and 
availability for machine harvest as compared to the traditional summer sowing (Singh and Saxena, 1996; Singh et al., 1997). In Turkey, chickpea is generally sown in spring and kernel yields are around $90-100 \mathrm{~kg} / \mathrm{da}$ levels. However, in Çukurova region with Mediterranean climate, winter sowings had kernel yields of about 250 - 300 kg/da (Engin, 1989; Özdemir et al., 1996; Anlarsal et al., 1999; Mart, 2000). Research findings revealed that in winter sowings, plant growth and development extended over a longer season as compared to summer sowings, plants were able to better utilize precipitation throughout this longer period, thus had greater above-ground biomass (biological yield) and about 50 - 100\% greater kernel yields (Singh et al., 1990).

This study was conducted to present the performance of different chickpea cultivars in terms of yield and yield components under Kahramanmaraş ecological conditions and to determine the best cultivar/cultivars for Kahramanmaraş province.

\section{MATERIALS AND METHODS}

This study was conducted over the experimental fields of Eastern Mediterranean Transitional Zone Agricultural Research Institute in 2014-2015 cropping years. Kahramanmaraş province is located in Mediterranean region between $37^{\circ} 38^{\prime}$ north latitudes and $36^{\circ} 37^{\prime}$ east longitudes and average altitude of the province is $568 \mathrm{~m}$. Mediterranean climate is dominant in the region. Winters are warm and rainy, summers are hot and dry, day/night temperature difference is low.

Cevdetbey, Işık-05, Azkan, Sarı-98, Çağatay, Menemen-92, Aksu, Hisar, Çakır, Aydın-92, Yaşa-05 registered chickpea cultivars and two local cultivars were used as the plant material of the study. Experiments were conducted in randomized blocks design with 3 replications. Plots were $5 \mathrm{~m}$ long, row spacing was $0.70 \mathrm{~m}$ and on-row plant spacing was $0.10 \mathrm{~m}$. Each plot had 4 rows planted. Plot size was $3 \times 0.70 \mathrm{~m} \times 5 \mathrm{~m}=10.5 \mathrm{~m}^{2}$. Manual sowing was practiced on plant rows and $3 \mathrm{~kg} \mathrm{~N}$ and 6 $\mathrm{kg} \mathrm{P}$ were applied (18-46-0) at sowing. Throughout the growing season, manual weeding was practiced for weed control. Plants were grown without irrigation.

At harvests, one row from each side and $50 \mathrm{~cm}$ from the top and bottom of the plots were omitted as to consider side effects. Measurement, counting and blending of harvested plants were conducted and average of measurement values were taken. Kernel yield per unit area was determined after drying and threshing the plants. Plant height, the first pod height, number of branches per plant, number of pod per plant, number of kernels per plant, kernel weight per plant, yield per decare and hundred-kernel weight were determined in accordance with the methods specified in Singh et al. (1991), Özekinci (2014), Aktaş (2017), Gürbüz (2017) and Çiftçi and Şehirali (1984). Experimental data were subjected to analysis of variance with the use of SAS software and significant means were compared with the use of Duncan's multiple range test (SAS, 1999).

\section{RESULTS AND DISCUSSIONS}

Differences in investigated parameters of the genotypes were found to be significant. Plant height of chickpea genotypes varied between $78.77-58.90 \mathrm{~cm}$ with the greatest value from Hisar cultivar $(78.77 \mathrm{~cm})$ and he lowest value from Çağatay cultivar $(58.90 \mathrm{~cm})$. Plant height is positively influenced by long precipitated vegetation season, but negatively influenced by hot and dry seasons (A ğsakallı and Olgun, 1999). Greater plant heights may also be attributed to cool season, fertile and humid soils (Biçer and Şakar, 2007). Differences in plant heights of the genotypes might have been resulted from plant genetics, sowing density, environmental and climate conditions throughout the growing season (Bayrak et al., 2015). The greatest first pod height $(38.60 \mathrm{~cm})$ was observed in Hisar cultivar, it was followed by Yaşa-05 $(37.63 \mathrm{~cm})$ and Aydın $(37.60 \mathrm{~cm})$ cultivars and the 
lowest value $(25.50 \mathrm{~cm})$ was observed in Çağatay cultivar. The first pod height is generally influenced by plant genetics and environmental factors (Fehr, 1987). The cultivars with greater first pod heights are recommended to farmers due to availability for machine harvest. The first pod height is also influenced by plant height, cultivar, soil and climate conditions, sowing time (summer or winter) (Bayrak et al., 2015).

Table 1. Data of plant height, first pod height, number of branches and pods per plant of Chickpea genotypes

\begin{tabular}{lllll}
\hline Genotypes & $\begin{array}{l}\text { Plant Height } \\
(\mathbf{c m})\end{array}$ & $\begin{array}{l}\text { First pod height } \\
(\mathbf{c m})\end{array}$ & $\begin{array}{l}\text { Number of } \\
\text { branches per } \\
\text { plant }\end{array}$ & $\begin{array}{l}\text { Number of pods } \\
\text { per plant }\end{array}$ \\
\hline Işık-05 & $71.57 \mathrm{bcd}$ & $32.30 \mathrm{def}$ & $3.60 \mathrm{bc}$ & $67.60 \mathrm{bcd}$ \\
Azkan & $70.77 \mathrm{cde}$ & $34.70 \mathrm{~cd}$ & $4.17 \mathrm{a}$ & $64.93 \mathrm{bcde}$ \\
Sar1-98 & $69.33 \mathrm{cde}$ & $32.47 \mathrm{def}$ & $3.87 \mathrm{ab}$ & $68.07 \mathrm{bcd}$ \\
Hisar & $78.77 \mathrm{a}$ & $38.60 \mathrm{a}$ & $3.67 \mathrm{~b}$ & $50.03 \mathrm{~g}$ \\
Çakır & $69.97 \mathrm{cde}$ & $33.70 \mathrm{cde}$ & $4.17 \mathrm{a}$ & $59.13 \mathrm{fg}$ \\
Aydın & $72.23 \mathrm{bc}$ & $37.60 \mathrm{ab}$ & $3.93 \mathrm{ab}$ & $72.83 \mathrm{~b}$ \\
Yaşa-05 & $76.27 \mathrm{ab}$ & $37.63 \mathrm{ab}$ & $3.30 \mathrm{c}$ & $59.37 \mathrm{ef}$ \\
Menemen & $65.47 \mathrm{e}$ & $31.97 \mathrm{ef}$ & $4.10 \mathrm{a}$ & $60.13 \mathrm{de}$ \\
Cevdetbey & $62.28 \mathrm{cde}$ & $31.70 \mathrm{ef}$ & $3.87 \mathrm{ab}$ & $63.90 \mathrm{cde}$ \\
Aksu & $72.80 \mathrm{bc}$ & $35.50 \mathrm{bc}$ & $3.93 \mathrm{ab}$ & $51.80 \mathrm{fg}$ \\
Yerli 1 & $68.80 \mathrm{cde}$ & $30.43 \mathrm{f}$ & $3.67 \mathrm{ab}$ & $69.33 \mathrm{bc}$ \\
Yerli 2 & $66.53 \mathrm{ed}$ & $31.03 \mathrm{f}$ & $3.60 \mathrm{~b}$ & $48.80 \mathrm{~g}$ \\
Çağatay & $58.90 \mathrm{f}$ & $25.50 \mathrm{~g}$ & $2.55 \mathrm{bc}$ & $80.77 \mathrm{a}$ \\
\hline Means & 69.51 & 31.31 & 3.84 & 62.82 \\
\hline
\end{tabular}

The greatest number of branches per plant was observed in Çakır, Azkan (4.17 branches) and Menemen (4.10 branches) cultivars and the lowest number of branches per plant was observed in Çağatay cultivar (2.55 branches). Biçer and Tonçer (2012) indicated that plant density had significant effects on number of branches per plant and reported decreasing number of branches with increasing plant densities.

The greatest number of pods per plant ( 80.77 pods) was observed in Çağatay cultivar and the lowest number of pods per plant (48.80 pods) was observed in Yerli 2 cultivar. Atmaca et al. (2009) reported increasing number of pods per plant with increasing on-row plant spacings. Topalak and Ceyhan (2015) and Ceran and Önder (2016) reported decreasing number of pods per plant with delayed sowing dates.

The greatest number of kernels per plant ( 86.07 kernels) was observed in Çağatay cultivar and the lowest number of kernels per plant (45.27 kernels) was observed in Aksu cultivar. Number of kernels per plant is generally influenced by cultivar, sowing type and density, type of fertilizer and fertilization time (Aktaş, 2017). Number of kernels per plant also exhibit significant variations based on the genotypes (Shrivastava et al., 1990). In terms of kernel weight per plant, the greatest value $(27.72 \mathrm{~g})$ was observed in Çağatay cultivar and the lowest values were seen in Yaşa-05 (19.37 g), Aksu (19.4 g) and Hisar (19.57 g) cultivars. 
Current Trends in Natural Sciences

Vol. 10, Issue 19, pp. 246-251, 2021

https://doi.org/10.47068/ctns.2021.v10i19.032

Current Trends in Natural Sciences (on-line)

ISSN: 2284-953X

Current Trends in Natural Sciences (CD-Rom)

ISSN: 2284-9521

ISSN-L: 2284-9521

ISSN-L: 2284-9521

Table 2. Data for number of kernels per plant, kernel weight per plant, 100 kernel weight and kernel yield of Chickpea genotypes

\begin{tabular}{lcccc}
\hline Genotypes & $\begin{array}{c}\text { Number of } \\
\text { kernels per plant }\end{array}$ & $\begin{array}{c}\text { Kernel weight } \\
\text { per plant }(\mathbf{g})\end{array}$ & $\begin{array}{c}\text { 100-kernel } \\
\text { weight }(\mathbf{g})\end{array}$ & $\begin{array}{c}\text { Kernel yield } \\
\text { (kg/da) }\end{array}$ \\
\hline Işı1k-05 & $57.81 \mathrm{c}$ & $25.49 \mathrm{ab}$ & $43.80 \mathrm{bc}$ & $311.27 \mathrm{de}$ \\
Azkan & $53.69 \mathrm{~cd}$ & $23.67 \mathrm{abc}$ & $44.14 \mathrm{bc}$ & $352.00 \mathrm{~cd}$ \\
Sar1-98 & $47.53 \mathrm{~d}$ & $23.43 \mathrm{abc}$ & $49.75 \mathrm{a}$ & $312.87 \mathrm{ed}$ \\
Hisar & $46.99 \mathrm{~d}$ & $19.57 \mathrm{c}$ & $43.07 \mathrm{bc}$ & $267.93 \mathrm{e}$ \\
Çakır & $49.17 \mathrm{~cd}$ & $22.20 \mathrm{abc}$ & $44.93 \mathrm{bc}$ & $425.40 \mathrm{a}$ \\
Aydın & $71.72 \mathrm{~b}$ & $26.50 \mathrm{ab}$ & $35.73 \mathrm{~cd}$ & $354.40 \mathrm{~cd}$ \\
Yaşa-05 & $51.14 \mathrm{~cd}$ & $19.37 \mathrm{c}$ & $39.64 \mathrm{~cd}$ & $411.80 \mathrm{ab}$ \\
Menemen & $52.45 \mathrm{~cd}$ & $25.73 \mathrm{ab}$ & $39.61 \mathrm{~cd}$ & $419.00 \mathrm{ab}$ \\
Cevdetbey & $46.46 \mathrm{~d}$ & $23.07 \mathrm{abc}$ & $49.80 \mathrm{a}$ & $373.67 \mathrm{bc}$ \\
Aksu & $45.27 \mathrm{~d}$ & $19.40 \mathrm{c}$ & $42.94 \mathrm{c}$ & $357.20 \mathrm{~cd}$ \\
Yerli 1 & $74.62 \mathrm{~b}$ & $24.63 \mathrm{abc}$ & $34.54 \mathrm{de}$ & $415.00 \mathrm{ab}$ \\
Yerli 2 & $68.51 \mathrm{~b}$ & $21.77 \mathrm{bc}$ & $31.83 \mathrm{e}$ & $308.20 \mathrm{de}$ \\
Çağatay & $86.07 \mathrm{a}$ & $27.72 \mathrm{a}$ & $32.72 \mathrm{e}$ & $301.13 \mathrm{e}$ \\
\hline Means & 57.89 & 19.91 & 40.96 & 333.07 \\
\hline
\end{tabular}

The 100-kernel weights of chickpea genotypes varied between $31.83-49.80 \mathrm{~g}$ with an average value of $40.96 \mathrm{~g}$, the greatest values in Cevdetbey and Sar1-98 cultivars and the lowest value in Yerli 2 cultivar. Kernel size is largely influenced by cultivar genetics and environmental factors. Similar with the present findings, Singh and Tuwate (1980), Aydin (1988) and Sharma et al. (1988) also reported that kernel size, thus 100-kernel weights varied with the genotypes.

Kernel yields of hte present genotypes varied between $267.93-425.40 \mathrm{~kg} / \mathrm{da}$ with an average value of $333.07 \mathrm{~kg} / \mathrm{da}$, the greatest value in Çakır cultivar $(425.40 \mathrm{~kg} / \mathrm{da})$ and the lowest values in Hisar $(267.93 \mathrm{~kg} / \mathrm{da})$ and Çağatay $(301.13 \mathrm{~kg} / \mathrm{da})$ cultivars. Differences in kernel yields of the genotypes might have resulted from differences in environmental adaptation, soil and climate parameters throughout the growing season (Gökkuş et al., 1996; Pundir et al., 1988).

\section{CONCLUSIONS}

In present study, conducted in 2014-2015 cropping year at Kahramanmaraş location, yield and yield components of different chickpea genotypes were investigated. The greatest kernel yields were obtained from Çakır, Menemen-92, Yerli 1 and Yaşa-05 cultivars and these cultivars had yield levels of greater than $400 \mathrm{~kg} / \mathrm{da}$. Apart from these genotypes, Çağatay cultivar was found to be prominent for number of pods per plant, number of kernels per plant and kernel weight per plant.

\section{ACKNOWLEDGEMENTS}

This study was derived from a Graduate Thesis.

\section{REFERENCES}

Ağsakallı, A., Olgun, M., (1999). Erzurum Şartlarında Nohut Islahı İçin Seleksiyon Kriterlerinin Tespiti [Determination of Selection Criteria for Chickpea Breeding in Erzurum Conditions]. Türkiye 3. Tarla Bitkileri Kongresi, ÇayırMera Yembitkileri ve Yemeklik Tane Baklagiller, III: 324-329. 15-20 Kasım, Adana. 
Aktaş, Y. (2017). Demir ve Fosfor Uygulamalarının Nohutta (Cicer arietinum L.) Verim ve Verim Öğelerine Etkileri [Effects of Iron and Phosphorus Applications on Yield and Yield Components of Chickpea (Cicer arietinum L.)]. Yüzüncü Yıl Üniversitesi Fen Bilimleri Enstitüsü Tarla Bitkileri Anabilim Dall, Yüksek Lisans Tezi, Van.

Anlarsal, A.E., Yücel, C., Özveren, D. (1999). Çukurova Koşullarında Bazı Nohut Hatlarının Verim ve Verimle İlgili Özelliklerinin Saptanması Üzerine Bir Araştırma [A Study on the Determination of Yield and Yield-Related Characteristics of Some Chickpea Lines in Çukurova Conditions]. Türkiye 3. Tarla Bitkileri Kongresi, ÇayırMera Yembitkileri ve Yemeklik Tane Baklagiller, III: 342-347. 15-20 Kasim, Adana.

Atmaca, E., Çiftçi C.Y., Çakır, S., Akın R., Karaman Y. (2009). Eskişehir Koşullarında Bazı Nohut Çeşit ve Hatlarında Farklı Ekim Zamanı ve Sıra Arası Mesafelerinin Verim, Verim Unsurları ve Kalite Üzerine Etkisi [The Effect of Different Sowing Times and Row Spacing on Yield, Yield Components and Quality in Some Chickpea Cultivars and Lines in Eskişehir Conditions.]. Türkiye 8. Tarla Bit. Kon., 19-22 Ekim Hatay.

Aydın, N. (1988). Ankara Koşullarında Nohut (Cicer arietinum L.)'ta Ekim Zamanı ve Bitki Sıklığının Verim, Verim Komponentleri ve Antraknoza Olan Etkileri [The Effects of Sowing Time and Plant Density on Yield, Yield Components and Anthracnose in Chickpea (Cicer arietinum L.) in Ankara Conditions]. A. ̈.Fen Bilimleri Enstitüsü Doktora Tezi (Basılmamıș), 119 s., Ankara

Bayrak, H., Keleş, R., İmriz, G. (2015). Determination of Some Characteristics Related to Yield Components of Advanced Bredding Chickpea Lines and Varieties in Konya Ecological Conditions. Journal of Bahri Dagdas Crop Research, 4(2): 32-37.

Biçer, B.T., Sakar. D. (2007). Research Regarding the Agronomic Values of Several Chickpea Genotypes. Not. Bot. Hort. Agrobot. Cluj, 35 (1): 3742 (2007).

Ceran, F., Önder, M. (2016). Farklı Dönemlerde Ekilen Nohut Çeşidinde (Cicer arietinum L.) Bazı Tarımsal Özelliklerin Belirlenmesi. [Determination of Some Agricultural Characteristics of Chickpea Varieties (Cicer arietinum L.) Planted at Different Periods.] Selçuk Tarım Bilimleri Dergisi, 3(1):25-29.

Çiftçi, C.Y., Şehirali, S. (1984). Fasülye Çeşitlerinde Değişik Özelliklerin Fenotipik ve Genotipik Farklılıklarının Saptanmas1. [Determination of Phenotypic and Genotypic Differences of Different Traits in Bean Varieties.] Ankara Üniversitesi Fen Bilimleri Enst. Yayınları No:TB.4, Ankara 175.

Engin, M. (1989). Çukurova Koşullarında Yüksek Verimli Nohut Çeşitlerinin Belirlenmesi Üzerine Bir Araştırma [A Study on Determination of High Yielding Chickpea Varieties in Çukurova Conditions]. Ç.Ü. Ziraat Fakültesi Dergisi, 4(6):93-103.

Eser, D. (1981). Yemeklik Tane Baklagiller. [Edible Grain Legumes.] A.Ü.Ziraat Fakültesi. Teksir No.59, Ankara 98.

Fehr, W.R. (1987). Genotype* Environment Interaction. Principles of Cultivar Development, Vol: I. Theory and Tecnique (Ed. W.R. Fehr). Macmillan Publishing Company, New York, pp: 247-260

Gökkuş, A., Bakoğlu A., Koç, A. (1996). Bazı adi fiğ (Vicia sativa L.) Hat ve Çeşitlerinin Erzurum Sulu Şartlarına Adaptasyonu Üzerine Bir Çalışma [A Study on the Adaptation of Some Common Vetch (Vicia sativa L.) Lines and Varieties to Erzurum Succulent Conditions.]. Türkiye 3. Çayır-Mera ve Yembitkileri Kongresi, 17-19 Haziran, Erzurum, 674-678.

Gürbüz, S. (2017). Farklı Ekim Zamanı ve Sira Arası Mesafelerinin Nohutta (Cicer aretinum L.) Verim ve Verim Unsurlarına Etkisi [The Effect of Different Sowing Times and Row Spacing on Yield and Yield Components of Chickpea (Cicer aretinum L.)]. Van Yüzüncü Yıl Üniversitesi Fen Bilimleri Enstitüsü Tarla Bitkileri Anabilim Dall, Yüksek Lisans Tezi, Van.

Mart, D. (2000). Çukurova Koşullarında Nohut (Cicer arietinum L.)'da Bazı Önemli Özellikler Yönünden Genotip x Çevre İnteraksiyonlan ve Uyum Yeteneklerinin Saptanması Üzerine Bir Araştırma [A Study on the Determination of Genotype x Environment Interactions and Adaptability in terms of Some Important Traits of Chickpea (Cicer arietinum L.) in Çukurova Conditions]. Ç.Ü. Fen Bilimleri Enstitüsü, Tarla Bitkileri Anabilim Dall, Doktora Tezi, Adana, 220.

Özdemir, S., Mart, D., Anlarsal, A.E. (1996). Değişik Ekim Sıklı̆̆ı Uygulamasının Üç Nohut Çeşidinde Verim ve Verim Unsurları Üzerine Etkileri [Effects of Different Sowing Density Applications on Yield and Yield Components in Three Chickpea Varieties]. Ç. Ü. Zir. Fak. Dergisi, 11(1), 175-184.

Özekinci, B. (2014). Mardin Ekolojik Koşullarında Nohut (Cicer arietinum L.)'da Farklı Bitki Sıklıklarının Verim ve Bazı Verim Öğelerine Etkisi [The Effect of Different Plant Densities on Yield and Some Yield Components of Chickpea (Cicer arietinum L.) in Mardin Ecological Conditions.]. Yüzüncü Yıl Üniversitesi Fen Bilimleri Enstitüsü Tarla Bitkileri Anabilim Dalı, Yüksek Lisans Tezi, Van.

Pundir, R.P.S., Reddy, K.N., Melik, H.M. (1988). Icrisat Chickpea Germplasm Catalog: Evaluation and Analysis. Icrisat Institute for the Semi-Arid Tropics Patancheru, India., A. P. 502324. 


\section{Current Trends in Natural Sciences}

Vol. 10, Issue 19, pp. 246-251, 2021

https://doi.org/10.47068/ctns.2021.v10i19.032

Current Trends in Natural Sciences (on-line)

ISSN: 2284-953X

Current Trends in Natural Sciences (CD-Rom)

ISSN: 2284-9521

ISSN-L: 2284-9521

ISSN-L: 2284-9521

SAS. (1999). SAS User's Guide: Statistic. Statistical Analysis Systems Institute Inc., Cary, NC.

Sharma, M.L., Chaukan, Y.S., Bharadwaj, G.S., Sharma, R.K. (1988). Relative Performance of Chickpea Varieties to Sowing Dates. Indian Journal Agronomy, 33(4 ): 452.

Shrivastava, P.P., Das, K., Prasad, S. (1990). Effect of Roasting Process Variables on In Vitro Protein Digestibility of Bengalgram, Maize and Soybean. Food Chemistry, 35: 31-37.

Singh, K.B., Tuwate, S. (1980). Variability for Seed Size and Seeds Size Per Pod in the Kabuli Chickpea Germplasm. International Chickpea Newsletter, 2; 4 -5.

Singh, K.B., Williams, P.C., Nakkaul, H. (1990). The Effects of Growth Season, Region and Sowing Date on Some Quality Parameters in Kabuli Chickpea. Journal of the Science of Food and Agricultere, 54:3, 429-441

Singh, K.B., Holly, L., Bejiga, G. (1991). A Catolog of Kabuli Chickpea Germplasm. ICARDA, p. 398.

Singh, K.B., Saxena, M.C. (1996). Winter Chickpea in Mediterranean-Type Environments. A Technical Bulletin, p: 131. ISBN: 92-9127-039-3 ICARDA. P.O. Box 5466, Aleppo, Syria.

Singh, K.B., Malhotra, R.S., Saxena, M.C., Bejiga, G. (1997). Superiority of Winter Sowing over Traditional Spring Sowing of Chickpea in The Mediterranean Region. Agron.J., 89: 112-118.

Smithson, J.B., Thompson, J.A., Summerfield, R.J. (1985). Chickpea (Cicer arietinum L.). p. 312-390. In:R.J. Summerfield and E.H. Roberts (eds.), Grain Legume Crops. Collins, London, UK.

Şehirali, S. (1988). Yemeklik Tane Baklagiller [Edible Grain Legumes.]. Ankara Üniversitesi Ziraat Fakültesi Yayınları: 1089, Ders Kitabi: 314, s. 435, Ankara.

Topalak, C., Ceyhan., E. (2015). Nohutta Farklı Ekim Zamanlarının Tane Verimi ve Bazı Tarımsal Özellikler Üzerine Etkileri [The Effects of Different Sowing Times on Grain Yield and Some Agricultural Characteristics in Chickpea.]. Selçuk Üniversitesi Tarım Bilimleri Dergisi, 2(2):130-139.

Wery, J., Grinac, P. (1983). Use of Legumes and Their Economic Importance: Technical Hand Book on Symbiotik Nitrogen Fixation. FAO, Rome, Italy. 